\title{
REVIEW
}

\section{Novel Insights into the Transmission of SARS-CoV-2 Through the Ocular Surface and its Detection in Tears and Conjunctival Secretions: A Review}

\author{
Noemi Güemes-Villahoz • Barbara Burgos-Blasco · Beatriz Vidal-Villegas • \\ Julián Garcia-Feijoo · Pedro Arriola-Villalobos · Jose María Martínez-de-la-Casa • \\ David Diaz-Valle · Anastasios G. Konstas
}

Received: May 26, 2020 / Published online: August 18, 2020

(C) The Author(s) 2020

\begin{abstract}
SARS-CoV-2 is a highly transmissible virus that spreads mainly via person-to-person contact through respiratory droplets, or through contact with contaminated objects or surfaces from an infected person. At present we are passing through a phase of slow and painful understanding of the origin, epidemiological profile, clinical spectrum, and risk profile of the virus. To the best of our knowledge there is only limited and contradictory evidence concerning SARS-CoV-2 transmission through other routes. Importantly, the eye may constitute not only a
\end{abstract}

Digital Features To view digital features for this article go to https://doi.org/10.6084/m9.figshare.12601931.

N. Güemes-Villahoz · B. Burgos-Blasco ·

B. Vidal-Villegas

Department of Ophthalmology, Instituto de

Investigación Sanitaria del Hospital Clínico San

Carlos (IdISSC), Madrid, Spain

J. Garcia-Feijoo · P. Arriola-Villalobos .

J. M. Martínez-de-la-Casa - D. Diaz-Valle

Department of Ophthalmology, Instituto de

Investigación Sanitaria del Hospital Clínico San

Carlos (IdISSC) IIORC, Universidad Complutense de

Madrid, ISCIII (OFTARED), Madrid, Spain

A. G. Konstas $(\bowtie)$

1st and 3rd University Departments of

Ophthalmology, Aristotle University of

Thessaloniki, Thessaloniki, Greece

e-mail: agkonstas@gmail.com potential site of virus replication but also an alternative transmission route of the virus from the ocular surface to the respiratory and gastrointestinal tract. It is therefore imperative to gain a better insight into the potential ophthalmological transmission route of the virus and establish directions on best practice and future models of care for ophthalmological patients. This review article critically evaluates available evidence on the ophthalmological mode of viral transmission and the value of earlier identification of the virus on the eye. More evidence is urgently needed to better evaluate the need for protective measures and reliable ocular diagnostic tests to diminish further pandemic spread.

Keywords: ACE-2; Conjunctivitis; Coronavirus; COVID-19; Eyewear protection; SARS-CoV-2; TMPRSS2; Transmission 


\section{Key Summary Points}

The presence of SARS-CoV-2 receptors in the eye may explain the viral tropism to the ocular tissue.

Although SARS-CoV-2 RNA has been detected in tear and conjunctival secretion specimens, accurate and consistent detection of ophthalmic involvement with conjunctival swaps remains problematic.

Importantly, the virus load in RT-PCR testing of tears and conjunctival samples often lies below detection threshold and consequently testing shows low sensitivity.

Future controlled studies are warranted to evaluate the precise rate and role of ocular involvement in SARS-CoV-2 infection.

The eye appears to play a key role in virus replication and downstream transmission. Therefore, better understanding and detection of viral transmission from the ocular surface to the respiratory and gastrointestinal tract are key topics of future research.

Personal protective equipment, including eye wear protection, is recommended.

\section{INTRODUCTION}

A novel coronavirus epidemic caused by the severe acute respiratory syndrome coronavirus2 (SARS-CoV-2) has spread to nearly every country in the world since the virus first emerged in China in December 2019. This virus causes the coronavirus disease 2019 (COVID19), which has at the time of writing been responsible for more than 10 million confirmed cases and 500,000 global fatalities, and has had an extraordinary socioeconomic impact worldwide. At present we are going through a phase of slow and painful understanding of the origin, epidemiological profile, clinical spectrum, and risk profile of the virus. SARS-CoV-2 is a highly transmissible virus that spreads mainly through person-to-person contact via respiratory droplets, or through contact with contaminated objects or surfaces from an infected person. Evidence regarding SARS-CoV-2 transmission through other routes, such as the fecal-oral route and through the ocular surface is currently under investigation. At present, the scientific evidence concerning ophthalmological transmission of the virus is limited and, in many cases, contradictory. It is therefore imperative to gain a better insight into the ophthalmological transmission route of the virus and to establish directions on best practice to plan future models of care for ophthalmological patients. We decided to critically review available evidence on the ophthalmological route of transmission and the value of earlier identification of the impact of COVID-19 upon the eye. The current work highlights the urgent need to delineate optimal protective measures and to evaluate the role of any potentially reliable future ocular diagnostic tests which could prevent further pandemic spread.

\section{METHODS}

We reviewed the pertinent literature through PubMed. A literature search was conducted under the topics COVID-19; SARS-CoV-2; transmission; eye; RT-PCR; tears; and conjunctiva. Relevant references for papers related to "SARS-CoV-2/COVID-19, ocular transmission and ophthalmology" published till 8 May 2020 were selected. The websites of the World Health Organization (WHO), the Centers for Diseases for Control and Prevention (CDC), the American Society of Ophthalmology, Spanish Society of Ophthalmology, and American and European Societies of Cataract and Refractive Surgery have been consulted. The literature search was conducted by all the authors, who selected, summarized, and agreed to the recommendations. This article is based on previously conducted studies and does not contain any studies 
with human participants or animals performed by any of the authors.

\section{SARS-COV-2: GENERAL FEATURES}

The new coronavirus SARS-CoV-2 belongs to the same betacoronavirus family as the severe acute respiratory syndrome coronavirus (SARS$\mathrm{CoV}$ ) and the Middle East respiratory syndromerelated coronavirus (MERS-CoV), which were responsible for the outbreaks of severe acute respiratory syndrome (SARS) in 2002 and 2012, respectively $[1,2]$. The genome of this enveloped positive-sense unsegmented single-strand RNA virus is 29,891 nucleotides in size, encoding 9860 amino acids. Overall, the genome of SARS-CoV-2 has $89 \%$ nucleotide identity with bat SARS-like-CoVZXC21 and 82\% with that of human SARS-CoV [3]. Viral genomic features are currently under intense scientific scrutiny in order to determine optimal diagnostic and therapeutic strategies for this emerging health threat.

Although the aforementioned viruses were also highly transmissible, the SARS-CoV-2 has spread more rapidly than its predecessors owing to a combination of extensive globalization of the economy and worldwide travel and the characteristics of the organism. This had led to a major global healthcare problem with severe global economic repercussions and a marked international recession.

\section{ROLE OF THE EYE IN SARS-COV-2 TRANSMISSION}

Unquestionably one of the most powerful potential tools to slow the spread of the virus is to deepen current knowledge of its transmission routes. SARS-CoV-2 spreads primarily through respiratory droplets and through contact with contaminated objects or surfaces from an infected person. There is more limited evidence regarding SARS-CoV-2 transmission through other routes, such as the fecal-oral route, which relies upon the detection of the virus in different types of tissue and fluids, including sputum, blood, and feces [4]. Moreover, SARS-CoV-2 has been detected in the tears and in conjunctival specimens collected from infected patients, suggesting that the ocular surface and the tears might represent a potential route for SARS-CoV2 infection $[5,6]$. Epidemiological evidence supports this theory. A multicenter study which documented potential risk factors for SARSCoV-2 transmission in patients requiring intubation [7] reported that unprotected eye contact with secretions from infected patients was the most predictive variable for transmission to healthcare workers. This observation highlighted the importance of using protective eyewear as an integral part of personal protective equipment to avoid infection. A similar case was reported earlier this year, when a doctor working in Wuhan, who wore an N95 mask, but did not wear eye protection, was subsequently infected with SARS-CoV-2 and presented with marked conjunctival hyperemia, suggesting that unprotected exposure of the eyes to SARSCoV-2 might be a route for disease transmission [8].

\section{OCULAR MANIFESTATIONS IN PATIENTS WITH COVID-19}

Cumulative evidence suggests that SARS-CoV-2 infection can cause conjunctivitis, either as an early sign of the infection or during hospitalization for COVID-19. The frequency of conjunctivitis in patients with COVID-19 has not been accurately quantified to date with reports indicating markedly variable prevalence. A study analyzing a sample of 1099 patients hospitalized for COVID-19 disease in China reported conjunctivitis symptoms in only $0.8 \%$ of afflicted patients (see Fig. 2 in [9]). In contrast, $\mathrm{Wu}$ and co-workers [10] reported a prevalence of conjunctival involvement as high as $31.6 \%$. The ocular symptoms related to COVID-19 are in most cases non-specific and resemble those of other forms of viral conjunctivitis. Recently, we evaluated the clinical characteristics of conjunctivitis in 14 Spanish patients with COVID19 [11]. Nearly half of them presented with signs of unilateral conjunctivitis. Overall, 11 patients $(79 \%)$ demonstrated mild ocular hyperemia and in 8 patients (57\%) moderate 
secretions were observed. None of our patients showed conjunctival petechiae, corneal infiltrates, membranes, or pseudomembranes, which may be found in other forms of conjunctivitis (e.g., adenoviral conjunctivitis). None of the Spanish patients experienced decreased vision and the mean duration of the conjunctivitis was 3 days (range 1-7 days).

The presence of ocular pathology other than conjunctivitis in patients with SARS-CoV-2 infection has yet to be described. Yuen et al. [12] evaluated 45 patients during the epidemic outbreak of SARS in Hong Kong and did not observe any ocular manifestations. However, retinal disorders such as retinal vasculitis, retinal degeneration, and blood-retinal barrier breakdown have all been reported in experimental animal models of coronavirus infection $[13,14]$. Moreover, it is important to highlight that SARS-CoV-2 infection appears to predispose patients to thrombotic disorders [15]. Therefore, the appearance of ocular vascular thrombotic events as a possible complication of the disease cannot be ruled out at this moment.

\section{OCULAR TROPISM AND RECEPTORS FOR SARS-COV-2}

The viral tropism to the ocular tissue could be partially explained by the presence of receptors for SARS-CoV-2 in the eye. The mechanism of SARS-CoV-2 cell entry depends on the viral spike $S$ proteins binding to cellular receptors and on $S$ protein priming by host cell proteases.

With regard to virus receptors, SARS-CoV-2 appears to employ angiotensin-converting enzyme 2 receptor (ACE2) for entry and transmembrane serine protease 2 (TMPRSS2) for S protein priming [16]. These receptors for SARS-CoV-2 have been identified in a wide range of human tissues, including lungs, small intestine, brain, kidney, and blood vessels among others [17]. Importantly, ACE2 and TMPRSS2 receptors have been identified in the eye not only on the ocular surface (cornea and conjunctiva) but also in deeper intraocular tissues, such as retina and choroid $[18,19]$.
A recent study has established that the expression level of these receptors in the conjunctiva is significantly higher than that in the cornea [18]. However, ACE2 expression levels on the ocular surface tissues are lower than those documented in the lung or the brain. Moreover, the binding capability of ACE2 protein on conjunctival and corneal epithelial cells to the spike proteins of SARS-CoV has been shown to be inferior to that of the lung [20].

\section{OCULAR SURFACE DEFENSE MECHANISMS}

The eye possesses mechanical, immunological, and anatomical defense mechanisms [21]. Mechanical barriers comprise the eyelids and eyelashes, as well as the tight intercellular junctions of the corneal epithelium and conjunctival mucosa. Moreover, tears contain antimicrobial proteins such as lactoferrin and immunoglobulins. Lactoferrin can inhibit the binding of SARS-CoV to ACE2, and tear IgA has proven to provide an effective immune defense against different kinds of viruses [22, 23].

The lacrimal drainage system acts as a physical self-cleaning system that clears pathogens from the ocular surface. However, this mechanism may prove counterproductive for SARSCoV-2 infection, since passage of infected tears through the nasolacrimal drainage system may serve as an entry route of the virus from the infected ocular surface to the respiratory and digestive tract [24]. The opposite passage of the virus from the nasal and oral mucosa to the eye seems less likely, but cannot be ruled out entirely.

A recent study evaluated the ocular tropism of SARS-CoV-2 in patients with confirmed COVID-19. Of the 56 subjects investigated there was only one patient who gave a history of prior pterygium surgery, with conjunctivitis and a positive PCR result from the conjunctival swab highlighting the importance of an intact ocular surface in resisting virus invasion [25]. These data could explain the virus' ocular tropism and account for the limited ocular involvement in a healthy eye. 


\section{VALUE OF SARS-COV-2 RNA DETECTION IN TEARS AND CONJUNCTIVAL SECRETIONS}

There is good evidence for the presence of SARSCoV-2 RNA in the tears of patients with COVID19 and conjunctivitis [5, 9]. Interestingly, reports describing the presence of the virus in tears and conjunctival secretions from patients with conjunctivitis did not detect the virus in patients without conjunctivitis. However, another study from Wuhan comprising 63 subjects with confirmed COVID-19 found that the only patient with conjunctivitis exhibited a negative conjunctival swab for SARS-CoV-2 RNA, whereas one patient without conjunctivitis had a positive conjunctival swab [26].

Undoubtedly, the most appropriate laboratory test for an accurate SARS-CoV-2 diagnosis is real-time polymerase chain reaction (RT-PCR) of a nasopharyngeal specimen [27]. Overall, this test demonstrates high specificity, and its sensitivity depends on the specimen and the time of testing during the course of the disease. Importantly, RT-PCR has also been used to detect viral nucleic acid in conjunctival samples. Our research team from Hospital Clinico San Carlos, Madrid, Spain collected conjunctival swab samples from 36 patients with laboratory-confirmed COVID-19. Of those, 18 patients exhibited conjunctivitis and 18 did not. SARSCoV-2 RNA was detected in the conjunctival swab of two patients (5.5\%). Among the 18 patients with conjunctivitis, only one $(5.5 \%)$ showed a positive result. Likewise, SARS-CoV-2 RNA was detected in only one patient without conjunctivitis (5.5\%) [28]. Therefore, our study revealed the same rate of positive results amongst the group with and without conjunctivitis, suggesting that detecting SARS-CoV-2 in ocular fluids is not dependent upon the clinical presence of conjunctivitis.

However, this extremely low positive rate of SARS-CoV-2 RNA test by RT-PCR in tears and conjunctival secretions from patients with laboratory-confirmed SARS-CoV-2 infection raises several doubts for its implementation. Firstly, the viral load in the conjunctival sample may prove to be insufficient for successful RT-PCR detection of the virus. The viral load obtained with a conjunctival specimen has been consistently shown to be less than that from a nasopharyngeal sample [9]. Therefore, it is possible that the viral load does not reach the threshold of detection of the virus, which could explain RT-PCR's low sensitivity in detecting SARS-CoV-2 RNA in tears and conjunctival secretions. Indeed, a recent paper by Zhou et al. [29] found that the proportion of positive results from conjunctival SARS-CoV-2 swabs was only $2.5 \%$ (only 3 patients from a cohort of 121 patients with confirmed COVID-19 tested positive for SARS-CoV-2 RNA with conjunctival swabs). This disconcerting finding is consistent with other studies that have reported a relatively low likelihood of detecting the virus from tear specimens of patients with COVID-19 [30]. Table 1 summarizes the relevant published articles which report RT-PCR results from tears and conjunctival secretions.

Since RT-PCR testing is highly specific, but appears to lack sufficient sensitivity, negative test results could in fact be false negative and thus may not exclude the presence of the virus. In this context it is noteworthy that sensitivity can be improved if multiple specimens are collected. A study by Xia et al. [5] tested tear and conjunctival secretions twice at an interval of 2-3 days and the results showed better detection and good consistency. However, it should be noted that limited resources and inadequate clinical access to patients with COVID-19 by and large limit the possibility of collecting multiple samples.

On the other hand, it is possible that the virus is only present in the tears and conjunctival secretions for a brief period of the disease duration, and thus the negative results may be due to incorrect timing of sample collection. A recent experimental study on rhesus macaques confirmed the short-lived presence of the virus in tears after conjunctival inoculation, indicating that although the virus-containing fluid can be found in ocular tissues, the majority of this fluid is drained into the nasopharyngeal space, or swallowed [31].

Another factor that may influence the negative results of conjunctival swabs is the stage of the disease at which the conjunctival sample is 
Table 1 Summary of published articles presenting RT-PCR results from tears and conjunctival secretions

\begin{tabular}{|c|c|c|c|c|c|c|}
\hline References & Journal & $\begin{array}{l}\text { Number of } \\
\text { cases }\end{array}$ & $\begin{array}{l}\text { RT-PCR+ in } \\
\text { tear and } \\
\text { conjunctival } \\
\text { samples }\end{array}$ & $\begin{array}{l}\text { Proportion } \\
\text { of RT- } \\
\text { PCR+ }\end{array}$ & $\begin{array}{l}\text { Conjunctivitis } \\
\text { ocular } \\
\text { symptoms }\end{array}$ & $\begin{array}{l}\text { Patients with } \\
\text { conjunctivitis and } \\
\text { positive RT-PCR }\end{array}$ \\
\hline $\begin{array}{l}\text { Wu et al. } \\
\text { [9] }\end{array}$ & $\begin{array}{l}J A M A \\
\quad \text { Ophthalmology }\end{array}$ & 28 & 2 & $7.1 \%$ & $11(39.2 \%)$ & $2(7.1 \%)$ \\
\hline $\begin{array}{l}\text { Zhou et al. } \\
\text { [29] }\end{array}$ & Ophthalmology & 121 & 3 & $2.5 \%$ & $8(6.6 \%)$ & $1(0.8 \%)$ \\
\hline $\begin{array}{l}\text { Xia et al. } \\
{[5]}\end{array}$ & $\begin{array}{r}\text { J. Medical } \\
\text { Virology }\end{array}$ & $\begin{array}{l}30 \text { ( } 2 \text { samples } \\
\text { separated } \\
2-3 \text { days per } \\
\text { eye) }\end{array}$ & $\begin{array}{l}1 \text { (2 samples } \\
\text { from the same } \\
\text { patient) }\end{array}$ & $3.3 \%$ & $1(3.33 \%)$ & $1(3.3 \%)$ \\
\hline $\begin{array}{l}\text { Zhang } \\
\text { et al. [6] }\end{array}$ & MedRxiv & 72 & 1 & $1.3 \%$ & $2(2.78 \%)$ & $1(1.3 \%)$ \\
\hline $\begin{array}{l}\text { Güemes- } \\
\text { Villahoz } \\
\text { et al. } \\
\text { [28] }\end{array}$ & $\begin{array}{l}\text { J. Medical } \\
\text { Virology }\end{array}$ & 36 & 2 & $5.5 \%$ & $18(50 \%)$ & $1(5.5 \%)$ \\
\hline
\end{tabular}

$N$ number of patients with positive RT-PCR form nasopharyngeal swabs, $R T$-PCR real-time polymerase chain reaction

collected. In a study by Chan et al. [32], tears swabs and conjunctival scrapings tested positive for SARS-CoV only when collected during the early stage of the infection, whereas the results were negative when specimens were collected at a later stage of the disease. In contrast, a case report of a 30-year-old man, who developed conjunctivitis on day 13 of the infection, demonstrated positive conjunctival swabs for SARS-CoV-2 over a period of 5 days until day 18 of his illness [9]. Similarly, in a case from Italy, SARS-CoV-2 RNA was detected in conjunctival secretions up to day 21 following hospital admission, and then 5 days after it became undetectable, but the virus was detected again in the ocular swab sample collected at day 27 [33].

\section{PROTECTIVE MEASURES AGAINST SARS-COV-2: DO WE NEED EYEWEAR PROTECTION?}

Despite ocular complications not being a common clinically detectable manifestation of
SARS-CoV-2 infection, recent evidence suggests that ocular exposure may represent a major transmission route for the virus. Thus, the eye not only constitutes a potential site of virus replication but more alarmingly also an insidious route for the transmission of the virus from the ocular surface to the respiratory and gastrointestinal tract. These findings highlight the relevance of appropriate use of personal protective gear for all healthcare personnel, including eye wear protection as a integral part of safety procedures against virus contamination.

\section{RISK OF SARS-COV-2 TRANSMISSION THROUGH OPHTHALMIC PROCEDURES}

As a direct result of the pandemic, the healthcare burden of patients without COVID-19 has been reduced, and only urgent ophthalmological procedures are performed in many countries. As a result of the proximity needed for ophthalmological examination and the 
unavoidable exposure to tears and ocular discharge during the exam, ophthalmologists are high-risk personnel for SARS-CoV-2 infection. Many ophthalmic instruments such as gonioscopy and laser lenses as well as ophthalmic ultrasound probes require direct or close contact with patients, which presumably increases the risk of viral transmission. A non-contact tonometer may create an aerosol when measuring intraocular pressure by punching air onto the cornea of patients; hence, it may also facilitate virus spread by aerosol transmission [34].

Moreover, since SARS-CoV-2 has been detected in tears and ocular fluids [11, 28], nasolacrimal duct syringing, probing, and intubation, which can cause splashing of tears and nasolacrimal secretions, may be considered aerosol-generating procedures [35]. In fact, many intraocular surgical procedures have been deemed aerosol-generating procedures. As such, endoscopic dacryocystorhinostomy should be classified as a high-risk procedure [36, 37]. Aerosol generation has been evaluated during phacoemulsification and suggestions have been made to minimize visible aerosol production by using a 2.2-mm phacoemulsification tip and reapplying hydroxypropyl methylcellulose (HPMC) coating of the cornea every minute during phacoemulsification [38]. Another study revealed that phacoemulsification did not generate aerosols of $10 \mu \mathrm{m}$ or smaller with continuous power using 80\% longitudinal, 100\% torsional, or $80 \%$ longitudinal setting with HPMC on the surface [39]. Visible aerosol generation during vitrectomy surgery has been also evaluated using a physical model, although this study did not find evidence of visible aerosol generation during simulated vitrectomy surgery [40].

Likewise, lasers, electrical cutting, and coagulation systems during surgery may generate an aerosol [41, 42]. Therefore, it is essential to adjust the equipment, surgical techniques, and work protocols to diminish the risk of exposure as much as possible. A modification in the design of the surgical fields as well as the use of three-dimensional display systems for ophthalmic surgery may increase the physical distance between surgeon and patient.
Several ophthalmological societies, such as the American Society of Ophthalmology, the American and European Societies of Cataract and Refractive Surgery, and the Spanish Society of Ophthalmology have issued a series of recommended standard operating protocols on the protective measures to be employed that have been updated with emerging evidence. All agree that it is safest to assume that any ophthalmic patient is potentially at risk of having been infected with SARS-CoV-2, especially in regions currently facing significant outbreaks of COVID-19. Overall, the recommended protocols include access control systems with interim guidance for triage, physical distancing measures, frequent and meticulous disinfection of common areas and equipment, the use of slit lamp barriers, or breath shields, a surgical mask for the patient, and personal protective equipment, including eye protection for healthcare personnel [43]. The role of telemedicine during the epidemic is also valuable in diminishing risk. Ideally, necessary surgery should be performed only after a negative diagnostic test for SARS-CoV-2 with PCR prior to surgery for patients and operating room staff alike, as well as requesting a signed informed consent from the patient explaining the risks arising from SARS-CoV-2 infection.

\section{CONCLUSION}

SARS-CoV-2 is a highly contagious virus that causes significant morbidity and mortality worldwide. Understanding its transmission routes is essential to reducing further spread of the pandemic. The eye appears to play a role in virus replication and downstream transmission. Accurate and consistent detection of ophthalmic involvement with conjunctival swabs remains problematic and variable since the virus load can remain below the threshold of detection and the timing of taking the swab sample is critical. Better understanding and detection of viral transmission from the ocular surface to the respiratory and gastrointestinal tract is required. Further large controlled studies are warranted to evaluate the precise rate and role of ocular involvement in SARS-CoV-2 
infection. The clinical value of tear and conjunctival testing and the risk of infection for ophthalmic personnel requires further elucidation.

\section{ACKNOWLEDGEMENTS}

Funding. No funding or sponsorship was received for this study or publication of this article.

Authorship. All named authors meet the International Committee of Medical Journal Editors (ICMJE) criteria for authorship for this article, take responsibility for the integrity of the work as a whole, and have given their approval for this version to be published.

Disclosures. Noemi Güemes-Villahoz, Barbara Burgos-Blasco, Beatriz Vidal-Villegas, Julián García-Feijoó, Pedro Arriola-Villalobos, Jose María Martínez de la Casa and David Diaz-Valle declare that they have no conflict of interest. Anastasios G. Konstas is a member of the journal's Editorial Board.

Compliance with Ethics Guidelines. This article is based on previously conducted studies and does not contain any studies with human participants or animals performed by any of the authors.

Data Availability. Data sharing is not applicable to this article as no datasets were generated or analyzed during the current study.

Open Access. This article is licensed under a Creative Commons Attribution-NonCommercial 4.0 International License, which permits any non-commercial use, sharing, adaptation, distribution and reproduction in any medium or format, as long as you give appropriate credit to the original author(s) and the source, provide a link to the Creative Commons licence, and indicate if changes were made. The images or other third party material in this article are included in the article's Creative Commons licence, unless indicated otherwise in a credit line to the material. If material is not included in the article's Creative Commons licence and your intended use is not permitted by statutory regulation or exceeds the permitted use, you will need to obtain permission directly from the copyright holder. To view a copy of this licence, visit http:// creativecommons.org/licenses/by-nc/4.0/.

\section{REFERENCES}

1. Peiris JSM, Yuen KY, Osterhaus ADME, Stöhr K. The severe acute respiratory syndrome. N Engl J Med. 2003;349(25):2431-41. https://doi.org/10.1056/ NEJMra032498.

2. WHO. Middle East respiratory syndrome coronavirus (MERS-CoV). 2020. https://www.who.int/ emergencies/mers-cov/en/. Accessed 2 May 2020.

3. Khailany RA, Safdar M, Ozaslan M. Genomic characterization of a novel SARS-CoV-2. Gene Rep. 2020 . https://doi.org/10.1016/j.genrep.2020. 100682 .

4. Wang W, Xu Y, Gao R, et al. Detection of SARSCoV-2 in different types of clinical specimens. JAMA. March 2020. https://doi.org/10.1001/jama. 2020.3786 .

5. Xia J, Tong J, Liu M, Shen Y, Guo D. Evaluation of coronavirus in tears and conjunctival secretions of patients with SARS-CoV-2 infection. J Med Virol. 2020. https://doi.org/10.1002/jmv.25725.

6. Zhang X, Chen X, Chen L, et al. The evidence of SARS-CoV-2 infection on ocular surface. Ocul Surf. 2020. https://doi.org/10.1016/j.jtos.2020.03.010.

7. Raboud J, Shigayeva A, McGeer A, et al. Risk factors for SARS transmission from patients requiring intubation: a multicentre investigation in Toronto, Canada. PLoS One. 2010;5(5):e10717. https://doi. org/10.1371/journal.pone.0010717.

8. Lu C-W, Liu X-F, Jia Z-F. 2019-nCoV transmission through the ocular surface must not be ignored. Lancet. 2020;395(10224):e39. https://doi.org/10. 1016/S0140-6736(20)30313-5.

9. Chen L, Liu M, Zhang Z, et al. Ocular manifestations of a hospitalised patient with confirmed 2019 novel coronavirus disease. Br J Ophthalmol. 2020. https://doi.org/10.1136/bjophthalmol-2020316304. 
10. Wu P, Duan F, Luo C, et al. Characteristics of ocular findings of patients with coronavirus disease (COVID-19) in Hubei Province, China. JAMA Ophthalmol. 2020;2020:1-8. https://doi.org/10.1001/ jamaophthalmol.2020.1291.

11. Güemes-Villahoz N, Burgos-Blasco B, Arribi-Vilela $A$, et al. SARS-CoV-2 RNA detection in tears and conjunctival secretions of COVID-19 patients with conjunctivitis. J Infect. 2020. https://www.ncbi. nlm.nih.gov/pubmed/32504746. Accessed 2 May 2020 .

12. Yuen KSC, Chan W-M, Fan DSP, Chong KKL, Sung JJY, Lam DSC. Ocular screening in severe acute respiratory syndrome. Am J Ophthalmol. 2004;137(4):773-4. https://doi.org/10.1016/j.ajo. 2003.09.060.

13. Vinores SA, Wang Y, Vinores MA, et al. Blood-retinal barrier breakdown in experimental coronavirus retinopathy: association with viral antigen, inflammation, and VEGF in sensitive and resistant strains. J Neuroimmunol. 2001;119(2):175-82. https://doi.org/10.1016/s0165-5728(01)00374-5.

14. Wang Y, Detrick B, Yu ZX, Zhang J, Chesky L, Hooks JJ. The role of apoptosis within the retina of coronavirus-infected mice. Invest Ophthalmol Vis Sci. 2000;41(10):3011-3018. https://www.ncbi.nlm. nih.gov/pubmed/10967058. Accessed 2 May 2020.

15. Bikdeli B, Madhavan MV, Jimenez D, et al. COVID19 and thrombotic or thromboembolic disease: implications for prevention, antithrombotic therapy, and follow-up. J Am Coll Cardiol. April 2020. https://doi.org/10.1016/j.jacc.2020.04.031.

16. Hoffmann $\mathrm{M}$, Kleine-Weber $\mathrm{H}$, Schroeder $\mathrm{S}$, et al. SARS-CoV-2 cell entry depends on ACE2 and TMPRSS 2 and is blocked by a clinically proven protease inhibitor. Cell. 2020;181(2):271-280.e8. https://doi.org/10.1016/j.cell.2020.02.052.

17. Li M-Y, Li L, Zhang Y, Wang X-S. Expression of the SARS-CoV-2 cell receptor gene ACE2 in a wide variety of human tissues. Infect Dis Poverty. 2020;9(1):45. https://doi.org/10.1186/s40249-02000662-X.

18. Zhang BN, Wang Q, Liu T, et al. Expression analysis of 2019-nCoV related ACE2 and TMPRSS2 in eye tissues. Zhonghua Yan Ke Za Zhi. 2020;56:E011. https://doi.org/10.3760/cma.j.cn112142-2020031000170 .

19. Senanayake P, Drazba J, Shadrach K, et al. Angiotensin II and its receptor subtypes in the human retina. Invest Ophthalmol Vis Sci. 2007;48(7): 3301-11. https://doi.org/10.1167/iovs.06-1024.
20. Sun Y, Liu L, Pan X, Jing M. Mechanism of the action between the SARS-CoV S240 protein and the ACE2 receptor in eyes. Int J Ophthalmol. 2006;6: 783-6.

21. Akpek EK, Gottsch JD. Immune defense at the ocular surface. Eye (Lond). 2003;17(8):949-56. https://doi.org/10.1038/sj.eye.6700617.

22. Lang J, Yang N, Deng J, et al. Inhibition of SARS pseudovirus cell entry by lactoferrin binding to heparan sulfate proteoglycans. PLoS One. 2011;6(8):e23710. https://doi.org/10.1371/journal. pone.0023710.

23. Coyle PK, Sibony PA. Viral antibodies in normal tears. Invest Ophthalmol Vis Sci. 1988;29(10): 1552-1558. https://www.ncbi.nlm.nih.gov/ pubmed/3170127. Accessed 2 May 2020.

24. Napoli PE, Nioi M, D'Aloja E, Fossarello M. The ocular surface and the coronavirus disease 2019: does a dual "ocular route" exist? J Clin Med. 2020. https://doi.org/10.3390/jcm9051269.

25. Hong N, Yu W, Xia J, Shen Y, Yap M, Han W. Evaluation of ocular symptoms and tropism of SARS-CoV-2 in patients confirmed with COVID-19. Acta Ophthalmol. April 2020. https://doi.org/10. 1111/aos.14445.

26. Zhou Y, Zeng Y, Tong Y, Chen C. Ophthalmologic evidence against the interpersonal transmission of 2019 novel coronavirus through conjunctiva. medRxiv. 2020. https://doi.org/10.1101/2020.02. 11.20021956.

27. WHO. Laboratory testing for 2019 novel coronavirus (2019-nCoV) in suspected human cases. Interim guidance. Jan 17, 2020. https://www.who. int/publications-detail/laboratory-testing-for-2019novel-coronavirus-in-suspected-human-cases20200117. Accessed 11 Feb 2020

28. Güemes-Villahoz N, Burgos-Blasco B, Arribi-Vilela A, et al. Detecting SARS-CoV-2 RNA in conjunctival secretions: is it a valuable diagnostic method of COVID-19? J Med Virol. 2020. https://doi.org/10. 1002/jmv.26219.

29. Zhou Y, Duan C, Zeng Y, et al. Ocular findings and proportion with conjunctival SARS-COV-2 in COVID-19 patients. Ophthalmology. April 2020. https://doi.org/10.1016/j.ophtha.2020.04.028.

30. Sun X, Zhang X, Chen X, et al. The infection evidence of SARS-COV-2 in ocular surface: a singlecenter cross-sectional study. medRxiv. 2020. https://doi.org/10.1101/2020.02.26.20027938.

31. Deng W, Bao L, Gao H, et al. Ocular conjunctival inoculation of SARS-CoV-2 can cause mild COVID- 
19 in rhesus macaques. bioRxiv. 2020. https://doi. org/10.1101/2020.03.13.990036.

32. Chan WM, Yuen KSC, Fan DSP, Lam DSC, Chan PKS, Sung JJY. Tears and conjunctival scrapings for coronavirus in patients with SARS. Br J Ophthalmol. 2004;88(7):968-9. https://doi.org/10.1136/ bjo.2003.039461.

33. Colavita F, Lapa D, Carletti F, et al. SARS-CoV-2 isolation from ocular secretions of a patient with COVID-19 in Italy with prolonged viral RNA detection. Ann Intern Med. April 2020. https://doi. org/10.7326/M20-1176.

34. Sun CB, Wang YY, Liu GH, Liu Z. Role of the eye in transmitting human coronavirus: what we know and what we do not know. Front Public Health. 2020;8:155. https://doi.org/10.3389/fpubh.2020. 00155 .

35. Ali MJ, Hegde R, Nair AG, et al. All India Ophthalmological Society-Oculoplastics Association of India consensus statement on preferred practices in oculoplasty and lacrimal surgery during the COVID-19 pandemic. Indian J Ophthalmol. 2020;68(6):974-80. https://doi.org/10.4103/ijo. IJO_1415_20.

36. Workman AD, Jafari A, Welling DB, et al. Airborne aerosol generation during endonasal procedures in the era of COVID-19: risks and recommendations. Otolaryngol Head Neck Surg. 2020. https://doi.org/ 10.1177/0194599820931805.

37. Cheung SSL, Wong CYK, Chan JCK, et al. Ophthalmology in the time of COVID-19: experience from Hong Kong Eye Hospital. Int J Ophthalmol.
2020;13(6):851-9. https://doi.org/10.18240/ijo. 2020.06 .01 .

38. Darcy K, Elhaddad O, Achiron A, et al. Reducing visible aerosol generation during phacoemulsification in the era of Covid-19. Eye (Lond). 2020. https://doi.org/10.1038/s41433-020-1053-3.

39. Lee H, Naveed H, Ashena Z, Nanavaty MA. Aerosol generation through phacoemulsification. J Cataract Refract Surg. 2020. https://doi.org/10.1097/j.jcrs. 0000000000000288.

40. Liyanage S, Ramasamy P, Elhaddad O, Darcy K, Hudson A, Keller J. Assessing visible aerosol generation during vitrectomy in the era of Covid-19. Eye (Lond). 2020. https://doi.org/10.1038/s41433-0201052-4.

41. Thamboo A, Lea J, Sommer DD, et al. Clinical evidence based review and recommendations of aerosol generating medical procedures in otolaryngology-head and neck surgery during the COVID-19 pandemic. J Otolaryngol Head Neck Surg. 2020;49(1):28. https://doi.org/10.1186/ s40463-020-00425-6.

42. Karjalainen M, Kontunen A, Saari S, et al. The characterization of surgical smoke from various tissues and its implications for occupational safety. PLoS One. 2018;13(4):e0195274. https://doi.org/10. 1371/journal.pone.0195274.

43. Amesty MA, Alió Del Barrio JL, Alió JL. COVID-19 disease and ophthalmology: an update. Ophthalmol Ther. 2020. https://doi.org/10.1007/s40123020-00260-y. 